
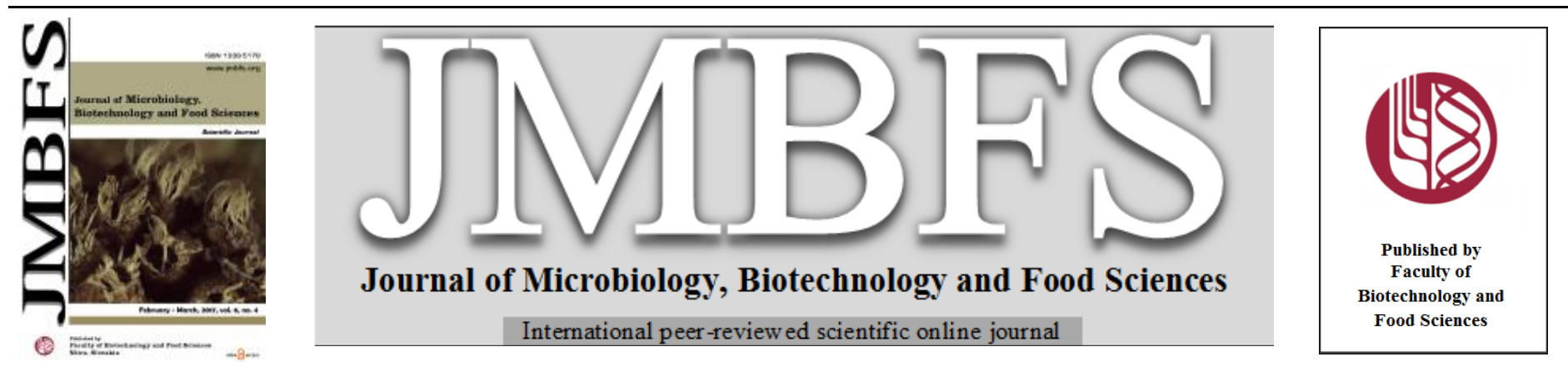

\title{
EVALUATION OF BIOCONVERSION CONDITIONS ON REUTERIN PRODUCTION USING RESPONSE SURFACE METHODOLOGY AND LISTERIA MONOCYTOGENES AS TARGET BACTERIA
}

\author{
Khanh Dang Vu ${ }^{I}$, Stéphane Salmieri ${ }^{1}$, Aguilar-Uscanga Blanca Rosa ${ }^{2}$, Monique Lacroix ${ }^{1 *}$

\section{Address(es):} \\ ${ }^{1}$ Research Laboratories in Sciences Applied to Food, Canadian Irradiation Center, INRS-Institut Armand-Frappier, Institute of Nutraceutical and Functional Foods, \\ 531, Boulevard des Prairies, Laval, Québec, Canada, H7V 1B7. \\ ${ }^{2}$ Centro Universitario de Ciencias Exactas e Ingeniería. Universidad de Guadalajara, Jalisco, México. Boulevard Marcelino García Barragán \#1421, Col. Olímpica. \\ Guadalajara, Jalisco C.P. 44430 México.
}

*Corresponding author: Monique.Lacroix@iaf.inrs.ca

doi: 10.15414/jmbfs.2017.6.4.1007-1011

\section{ARTICLE INFO}

Received 18.1.2017

Revised 15. 11. 2017

Accepted 5. 12. 2016

Published 1. 2. 2017

Regular article open $\partial_{\text {Access }}$

\begin{abstract}
The objective of this study was to evaluate the effect of bioconversion conditions on reuterin production by Lactobacillus reuteri using response surface methodology (RSM). A central composite design consisted of three independent factors at 5 levels: concentration of Lactococcus reuteri $(\log \mathrm{CFU} / \mathrm{ml})$, glycerol concentration $(\mathrm{mM})$, and incubation time $(\mathrm{h})$ was set up and consisted of 18 experimental runs. The dependant factor was the relative reuterin concentration expressed through its antibacterial activity (Units reuterin per $\mathrm{ml}$, $\mathrm{U} / \mathrm{ml}$ ) against $L$. monocytogenes using microbroth dilution assay. A polynomial equation for prediction of reuterin production (U/ml) produced by $L$. reuteri was created based on obtained data. Results showed that incubation time, bacterial and glycerol concentrations had linear positive effects on reuterin production. The quadratic effect of incubation time had negative effect on reuterin production in which at a fixed bacterial concentration of $L$. reuteri, a longer incubation time with low concentration of glycerol will cause the reduction in relative reuterin concentration. It was found that approximately $450 \mathrm{U} / \mathrm{ml}$ can be produced by $L$. reuteri with glycerol concentration ranging from 320 to $340 \mathrm{mM} \mathrm{mM}$, L. reuteri concentration of $9.4 \log \mathrm{CFU} / \mathrm{ml}$ and $2 \mathrm{~h}$ of incubation. Results demonstrated that applying suitable conditions for glycerol bioconversion into reuterin by L. reuteri, a high relative reuterin concentration could be obtained and used for food preservation against L. monocytogenes.
\end{abstract}

Keywords: Antibacterial activity, Reuterin, Lactobacillus reuteri, Listeria monocytogenes, response surface methodology

\section{INTRODUCTION}

Lactobacillus reuteri is a member of gastrointestinal bacteria of healthy human and animals. It has been demonstrated as a potential probiotic bacterium in biodetoxification and health stimulation, (van Niel et al., 2012) and in immunomodulation (Mechoud et al., 2012). Further, L. reuteri is well-known as a producer of 3-hydroxypropionaldehyde (3-HPA) or reuterin during anaerobic metabolism of glycerol (Axelsson et al., 1989; Chung et al., 1989). Glycerol is converted to reuterin by a coenzyme $\mathrm{B}_{12}$-dependent dehydratase (Talarico and Dobrogosz, 1990). Reuterin can be further reduced by NADH to form 1,3propanediol which is catalyzed by 1,3-propanediol: NAD oxidoreductase (Talarico et al., 1990). Reuterin can inhibit the growth of yeast, protozoa, and many bacteria, both Gram-negative and Gram-positive (Axelsson et al., 1989; Chung et al., 1989).

Reuterin is water soluble compound, and it is active in a wide range of $\mathrm{pH}$. It is also resistance to proteolytic and lipolytic enzymes (El-Ziney et al., 2000; Vollenweider and Lacroix 2004). Therefore, potential of using reuterin for preservation of food products are of great interest (El-Ziney and Debevere 1998; Arqués et al., 2004; Montiel et al.,, 2014). Reuterin could inhibit the growth of pathogenic bacteria such as Listeria monocytogenes, and Escherichia coli O157: H7 in milk and cottage cheese (El-Ziney and Debevere 1998), L. monocytogenes in cold-smoked salmon (Montiel et al., 2014). A synergistic effect of reuterin plus nisin against L. monocytogenes and Staphylococcus aureus was obtained in refrigerated milk at the end of storage of 12 days (Arqués et al., 2004).

It has been found that L. monocytogenes was more resistant to reuterin than some other bacteria. For example, reuterin at the same activity $(8 \mathrm{U} / \mathrm{ml})$ was more effective in eliminating Staphylococcus aureus than L. monocytogenes at $37^{\circ} \mathrm{C}$ in milk (Arqués et al., 2004). Similarly, it has been observed that E. coli strains were sensitive to reuterin than Listeria strains including L. monocytogenes (ElZiney et al., 2000). Thus, it is important to find suitable conditions so that $L$. reuteri can produce high reuterin concentration to eliminate $L$. monocytogenes in food products.

It has been demonstrated that several factors such as the glycerol and biomass concentrations, incubation time, temperature and $\mathrm{pH}$ can influence on reuterin production produced by $L$. reuteri (Lüthi-Peng et al., 2002a,b; Tobajas et al., 2007). However, most of studies focused on evaluation of varying effect of a single factor while other factors were fixed on reuterin activity and therefore, the possible interactive effects among different factors on reuterin production by $L$. reuteri could not be established.

Response surface methodology (RSM) is known as a combination of mathematical and statistical techniques for optimization of a process where dependent factors are affected by several independent factors. This method can be used to determine the possible interactive effects among different independent factors on the dependent factors in an experimental design (Adjalle et al., 2011; Khan et al., 2014).

Thus, the aim of this study was to evaluate the interactive effects of bioconversion condition on reuterin activity against L. monocytogenes using RSM. A central composite consisting of three independent factors (glycerol concentration, $L$. reuteri concentration and incubation time) at 5 levels was designed. The design formed 18 experimental bioconversion conditions. Reuterin production or relative reuterin concentration expressed through its activity (Units per $\mathrm{ml}, \mathrm{U} / \mathrm{ml}$ ) against L. monocytogenes was determined using microbroth dilution method.

\section{MATERIALS AND METHODS}

Bacterial and growth conditions

Lactobacillus reuteri ATTCC 53608 was used in this study. The stock culture of L. reuteri in MRS broth containing $10 \%$ glycerol was preserved as aliquot of 1 $\mathrm{ml}$ in cryovial tubes at $-80{ }^{\circ} \mathrm{C}$. Before each experiment, one $\mathrm{ml}$ of stock culture was inoculated into test tube containing $9 \mathrm{ml}$ of MRS broth, incubated at $37^{\circ} \mathrm{C}$ for 
$24 \mathrm{~h}$ to obtain pre-inoculum. Then, the pre-inoculum $(1.5 \mathrm{ml})$ was inoculated in Erlenmeyer containing $30 \mathrm{ml}$ of MRS broth and incubated at $37{ }^{\circ} \mathrm{C}$ for $24 \mathrm{~h}$ to obtain inoculum.

L. monocytogenes 2812 stock cultures were stored at $-80{ }^{\circ} \mathrm{C}$ in Tryptic Soya Broth broth medium containing glycerol $(10 \% \mathrm{v} / \mathrm{v})$. Before each experiment, stock cultures were grown through two consecutive $24 \mathrm{~h}$ growth cycles in Tryptic Soya Broth at $37{ }^{\circ} \mathrm{C}$. The cultivated cultures were centrifuged at $5000 \mathrm{~g}$ for 15 minutes and the obtained pellets were washed twice in sterile saline water $(0.85 \%$ $\mathrm{w} / \mathrm{v})$ to obtain working cultures containing approximately $10^{9} \mathrm{CFU} / \mathrm{mL}$. The working cultures were diluted in sterile saline water $(0.85 \%, \mathrm{w} / \mathrm{v})$ to have final concentration of $10^{6} \mathrm{CFU} / \mathrm{ml}$. This bacterial solution was then used for microbroth dilution assay to evaluate relative reuterin activity $(\mathrm{U} / \mathrm{ml})$.

\section{Biomass production of $L$. reuteri}

Preliminary experiment on the effect of fermentation time on reuterin production and on its antibacterial activity showed that biomass of $L$. reuteri collected at the end of exponential phase ( $24 \mathrm{~h}$ of fermentation) gave better antimicrobial activity against $L$. monocytogenes. Therefore, biomass of $L$. reuteri was collected at $24 \mathrm{~h}$ of fermentation.

The inoculum of L. reuteri was inoculated (5\%,v/v) into Erlenmeyers containing $200 \mathrm{ml}$ of MRS broth. The Erlenmeyers were incubated in an incubator at $37{ }^{\circ} \mathrm{C}$ under static conditions for $24 \mathrm{~h}$. The fermented broth was collected in centrifugal tubes and centrifuged at $5,000 \mathrm{x} \mathrm{g}$ for $10 \mathrm{~min}$ at $4^{\circ} \mathrm{C}$. The supernatant was discarded and biomass was washed twice with $50 \mathrm{mM}$ sodium phosphate buffer ( $\mathrm{pH}$ 7.5) to eliminate residual components of culture medium (MRS broth). The washing step was conducted by suspended biomass in $50 \mathrm{mM}$ sodium phosphate buffer, then centrifuged at $5000 \mathrm{x}$ g for 10 minutes at $4^{\circ} \mathrm{C}$ and the supernatant was discarded after each washing step. Finally, biomass was suspended in $50 \mathrm{mM}$ sodium phosphate buffer ( $\mathrm{pH} 7.5)$. The cell concentration of L reuteri $(\mathrm{CFU} / \mathrm{ml})$ in suspended biomass was enumerated by 10 -fold serial dilution and plating on petri dishes containing MRS agar. Further, the suspended biomass was diluted by $1,1.2,1.4,1.6,1.8$ and 2 folds and the optical density (OD) values of diluted

solutions were recorded at $595 \mathrm{~nm}$. Based on cell concentration determined by plating counting method and the OD of different diluted solutions of suspended biomass, the linear correlation between $\mathrm{CFU} / \mathrm{ml}$ and OD values was established. This correlation helped to determine the approximately bacterial concentration of L. reuteri in subsequent experiments based on OD value of the cultures.

\section{Experimental design for reuterin production}

A central composite consisting of 3 independent factors (glycerol concentration, bacterial concentration and incubation time) at 5 levels (Table 1) was designed to find the suitable conditions for reuterin production against L. monocytogenes This included 18 experimental bioconversion conditions (Table 2).

Table 1 Level of independent factors in the central composite design

\begin{tabular}{lccccc}
\hline \multirow{2}{*}{ Independent factors } & \multicolumn{5}{c}{ Level } \\
\cline { 2 - 6 } & -2 & -1 & 0 & 1 & 2 \\
\hline Glycerol concentration $\left(\mathrm{X}_{1}, \mathrm{mM}\right)$ & 166 & 200 & 250 & 300 & 334 \\
Bacterial concentration $\left(\mathrm{X}_{2}, \log \right.$ & 8.0 & 8.3 & 8.7 & 9.1 & 9.40 \\
CFU/ml) & 0.3 & 1 & 2 & 3 & 3.7 \\
Incubation time $\left(\mathrm{X}_{3}, \mathrm{~h}\right)$ & & &
\end{tabular}

Bacterial suspension of $L$. reuteri at different concentrations was added into falcon tubes, and glycerol was added to obtain final concentration of bacteria and glycerol as required depending on each experimental condition (Table 2). The final volume of each falcon tube was $10 \mathrm{ml}$. The mixture in falcon tubes was mixed well and falcon tubes were anaerobically incubated at $37{ }^{\circ} \mathrm{C}$ for different periods (h) as required in the experimental design. Then, tubes were centrifuged at $5000 \mathrm{x} \mathrm{g}$ for 10 minutes and supernatant was collected. The supernatant was filtered through a $0.45 \mu \mathrm{m}$ filter. The supernatant was kept at $4{ }^{\circ} \mathrm{C}$ and used for evaluation of its activity against L. monocytogenes using microbroth dilution assay.

Table 2 Experimental runs and relative reuterin concentration

\begin{tabular}{|c|c|c|c|c|c|}
\hline $\begin{array}{l}\text { Experimental } \\
\text { condition }\end{array}$ & $\begin{array}{c}\text { Glycerol } \\
\text { concentration }(\mathbf{m M})\end{array}$ & $\begin{array}{c}\text { Bacterial } \\
\text { concentration (log } \\
\text { CFU/ml) }\end{array}$ & $\begin{array}{l}\text { Incubation time } \\
\text { (h) }\end{array}$ & $\begin{array}{l}\text { Observed relative } \\
\text { reuterin concentration } \\
(\mathrm{U} / \mathrm{ml})\end{array}$ & $\begin{array}{c}\text { Predicted } \\
\text { relative reuterin } \\
\text { concentration } \\
(\mathrm{U} / \mathrm{ml}) \\
\end{array}$ \\
\hline 1 & 200 & 8.3 & 1.0 & 64.0 & 57.5 \\
\hline 2 & 200 & 8.3 & 3.0 & 96.0 & 128.2 \\
\hline 3 & 200 & 9.1 & 1.0 & 256.0 & 237.8 \\
\hline 4 & 200 & 9.1 & 3.0 & 256.0 & 308.5 \\
\hline 5 & 300 & 8.3 & 1.0 & 96.0 & 96.5 \\
\hline 6 & 300 & 8.3 & 3.0 & 96.0 & 167.2 \\
\hline 7 & 300 & 9.1 & 1.0 & 256.0 & 276.8 \\
\hline 8 & 300 & 9.1 & 3.0 & 384.0 & 347.5 \\
\hline 9 & 166 & 8.7 & 2.0 & 192.0 & 204.9 \\
\hline 10 & 334 & 8.7 & 2.0 & 256.0 & 270.5 \\
\hline 11 & 250 & 8.0 & 2.0 & 128.0 & 86.7 \\
\hline 12 & 250 & 9.4 & 2.0 & 384.0 & 388.7 \\
\hline 13 & 250 & 8.7 & 0.3 & 64.0 & 78.8 \\
\hline 14 & 250 & 8.7 & 3.7 & 256.0 & 197.7 \\
\hline 15 & 250 & 8.7 & 2.0 & 256.0 & 237.7 \\
\hline 16 & 250 & 8.7 & 2.0 & 256.0 & 237.7 \\
\hline 17 & 250 & 8.7 & 2.0 & 256.0 & 237.7 \\
\hline 18 & 250 & 8.7 & 2.0 & 256.0 & 237.7 \\
\hline
\end{tabular}

Evaluation of reuterin production $(\mathrm{U} / \mathrm{ml})$ using microbroth dilution assay

Reuterin production was evaluated by relative reuterin concentration which is expressed through its antibacterial activity (U/ml) using dilution assay (Chung $\boldsymbol{e t}$ al., 1989). In this study, L. monocytogenes was used as target bacterial strain and the microbroth dilution assay with some modification was applied for evaluation of reuterin production (Turgis et al., 2012). The supernatants obtained from experimental conditions were diluted by $8,12,16,24,48,96,128$ and 192 times using sterile sodium phosphate buffer $(50 \mathrm{mM}, \mathrm{pH} 7.5)$. First, $125 \mu \mathrm{l}$ of sterile Mueller-Hinton Broth (MHB) were filled into wells of a microplate. Then, $50 \mu$ of reuterin solution at different concentrations were added into wells of eight columns of the microplate. Finally, $25 \mu \mathrm{l}$ of working culture of L. monocytogenes $\left(10^{6} \mathrm{CFU} / \mathrm{ml}\right)$ were inoculated into the wells of six rows of the microplate. The last two rows containing $\mathrm{MHB}$, different concentrations of reuterin and without $L$. monocytogenes served as blank. The columns containing MHB with $L$. monocytogenes and without reuterin served as positive control. The final volume of the wells in the microplate was 200 microliters. Thus, the final reuterin concentration in the tested wells was diluted by 4 fold. This factor plus the dilution level mentioned above $(8,12,16,24,48,96,128$ and 192) were considered in calculation the reuterin activity against L. monocytogenes. The microplate was incubated for $24 \mathrm{~h}$ at $37{ }^{\circ} \mathrm{C}$, then, the optical absorbance (OD) of the microplate was measured at $595 \mathrm{~nm}$ using an Ultra Microplate Reader (Biotek instruments, Winooski, VT, USA). Relative reuterin concentration (Unit reuterin per $\mathrm{ml}$ or $\mathrm{U} / \mathrm{ml}$ ) was calculated as the reciprocal of the highest dilution of the sample that can inhibit the growth of L. monocytogenes (Chung et al., 1989).

\section{Statistical analysis}

Data obtained from experimental design were used for analysis of variance (ANOVA), and regression analysis using STATISTICA 12 (STATSOFT Inc., Tulsa, US). A general second-order polynomial equation was built to predict reuterin production (equation 1 ).

$Y=B_{0}+\sum_{i=1}^{3} B_{i} X_{i}+\sum_{i=1}^{3} B_{i i} X_{i}^{2}+\sum_{i=1}^{2} \sum_{j=i+1}^{3} B_{i j} X_{i} X_{j}$ (equation 1$)$

where $\mathrm{Y}$ is the predicted response; $\mathrm{B}_{0}$, intercept; $\mathrm{X}_{\mathrm{i}}$ and $\mathrm{X}_{\mathrm{j}}$ are values of various levels of the independent variables; $\mathrm{B}_{\mathrm{i}}$ is the values of linear coefficients; and $\mathrm{B}_{\mathrm{ii}}$ is the values of quadratic coefficients and $\mathrm{Bij}$ is the values of the interaction between 2 independent factors (Adjallé et al., 2011). Response surface plots were created to show the effects between the independent variables (glycerol concentration $\left(\mathrm{X}_{1}\right)$, bacterial concentration $\left(\mathrm{X}_{2}\right)$ and incubation time $\left(\mathrm{X}_{3}\right)$ ) on the reuterin production $(\mathrm{U} / \mathrm{ml})$. 


\section{RESULTS}

Analysis of variance for reuterin production and regression coefficients of factors for the model

The relative reuterin concentrations $(\mathrm{U} / \mathrm{ml})$ of 18 experimental bioconversion conditions are presented in Table 2 . It can be observed that depending on conditions of three independent factors (glycerol, bacterial concentrations and incubation time), the observed relative reuterin concentration could vary from minimum of 64 to maximum of $384 \mathrm{U} / \mathrm{ml}$. The higher relative reuterin concentration $(\mathrm{U} / \mathrm{ml})$ of a sample means that even at higher factor of dilution of this sample, it can still have the capacity to eliminate L. monocytogenes in tested system.

Analysis of variance (ANOVA) was conducted and the model had a regression coefficient factor $\left(\mathrm{R}^{2}\right)$ of 0.89 , indicating that $89 \%$ of the variation in the responses could be explained by the combination of the responses. Further, there was no lack of fit of the model. Thus, the model can be used for prediction of reuterin production based on incubation time, glycerol, and bacterial concentration.

The reduced ANOVA table (after eliminating the factors which are not importan in the model) is presented in Table 3. It can be observed that the linear effect of bacterial concentration was a very important factor on reuterin production $(P=$ $0.000001)$. The linear and quadratic effects of incubation time were also important to affect reuterin production $(P=0.004)$. The linear effects of glycerol $(P=0.07)$ was important on reuterin production but less than those of incubation time and bacterial concentration (Table 3 ).

Table 3 Analysis of variance for reuterin production

\begin{tabular}{lccc}
\hline Source & Sum of square & df & $\boldsymbol{P}$ value \\
\hline $\begin{array}{l}\text { Glycerol concentration } \\
\text { (L)* }\end{array}$ & 5244.9 & 1 & 0.07 \\
$\begin{array}{l}\text { Bacterial concentration } \\
\text { (L) }\end{array}$ & 110631.7 & 1 & 0.000001 \\
Incubation time (L) & 17075.4 & 1 & 0.004 \\
Incubation time (Q) & 16846.3 & 1 & 0.004 \\
Total sum of square & 167876.5 & & \\
\hline
\end{tabular}

Table 4 Regression coefficients of the predictive model

\begin{tabular}{lcc}
\hline Factors & $\begin{array}{c}\text { Regression } \\
\text { Coefficient }\end{array}$ & $\boldsymbol{P}$ value \\
\hline Constant & -2032.00 & 0.000001 \\
Glycerol concentration (L)* & 0.39 & 0.07 \\
Bacterial concentration (L) & 225.39 & 0.000001 \\
Incubation time (L) & 175.94 & 0.0009 \\
Incubation time (Q) & -35.15 & 0.004 \\
\hline
\end{tabular}

* L means Linear effect, Q means Quadratic effect.

The final regression coefficients of the factors for the model are presented in Table 4 and were used to create a predictive model (equation 2):

$\mathrm{Y}=-2032.00+0.39 \mathrm{X}_{1}+225.39 \mathrm{X}_{2}+175.94 \mathrm{X}_{3}-35.15 \mathrm{X}_{3}^{2}$ (equation 2)

where $\mathrm{Y}=$ reuterin activity $(\mathrm{U} / \mathrm{ml}) ; \mathrm{X}_{1}$ is glycerol concentration $(\mathrm{mM}) ; \mathrm{X}_{2}$ is $L$ reuteri concentration ( $\log \mathrm{CFU} / \mathrm{ml})$; and $\mathrm{X}_{3}$ is incubation time $(\mathrm{h})$.

It can be observed that all linear effect of glycerol, biomass and incubation time have positive effects on the reuterin production while the quadratic effect of incubation time have a negative impact on the activity (Table 3). Based on the model, the predicted values of relative reuterin concentration $(\mathrm{U} / \mathrm{ml})$ of experimental runs are also presented in the Table 2.

Response surface plots of the interactive effects between different independent factors on reuterin activity

Response surface plots of the relation between different independent factors on the reuterin production was created and expressed in Figure 1 to Figure 3

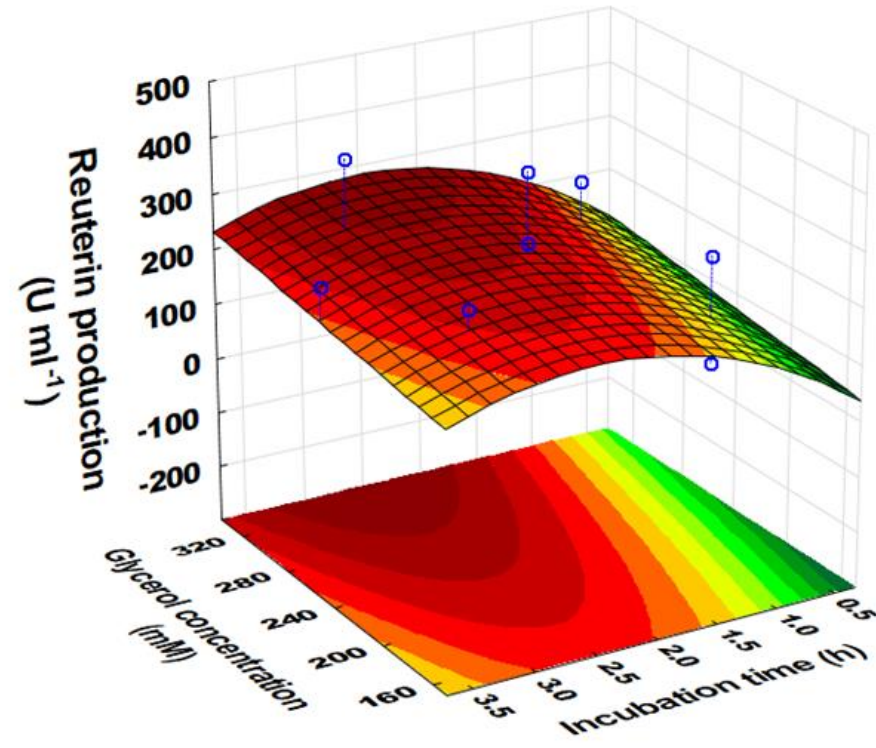

Figure 1 Effect of glycerol concentration and incubation time on reuterin production (bacterial concentration was fixed at $8.7 \log \mathrm{CFU} / \mathrm{ml}$ )

Figure 1 presents the relation between glycerol concentration $\left(\mathrm{X}_{1}, \mathrm{mM}\right)$ and incubation time $\left(\mathrm{X}_{3}, \mathrm{~h}\right)$ on reuterin production when the concentration of $L$. reuteri $\left(\mathrm{X}_{2}\right)$ was kept constant at $8.7 \log \mathrm{CFU} / \mathrm{ml}$. It can be observed that increase in both incubation time (from 0.5 to about $2.5 \mathrm{~h}$ ) and glycerol concentration (140$340 \mathrm{mM}$ ) can cause an increase in relative reuterin concentration; however, further increase in incubation time and at low glycerol concentration, a decrease in relative reuterin concentration can be occurred. For example, when the incubation time is around $1 \mathrm{~h}$, and glycerol concentration is from 140 to approximately $200 \mathrm{mM}$, a relative reuterin concentration of equal or less than 140 $\mathrm{U} / \mathrm{ml}$ can be produced by $8.7 \log \mathrm{CFU} / \mathrm{ml}$ of L. reuteri (Figure 1). When glycerol concentration is from 280 to $340 \mathrm{mM}$ and the incubation time is from 2 to $3 \mathrm{~h}$, almost $300 \mathrm{U} / \mathrm{ml}$ can be produced by the same concentration of L reuteri $(8.7 \mathrm{log}$ $\mathrm{CFU} / \mathrm{ml})$. However, when the incubation time is more than $3 \mathrm{~h}$ and glycerol concentration is less than $240 \mathrm{mM}$, relative reuterin concentration of less than $200 \mathrm{U} / \mathrm{ml}$ can be obtained (Figure 1). Thus with a fixed bacterial concentration o $L$. reuteri, a longer incubation time with low concentration of glycerol will cause the reduction in reuterin production.

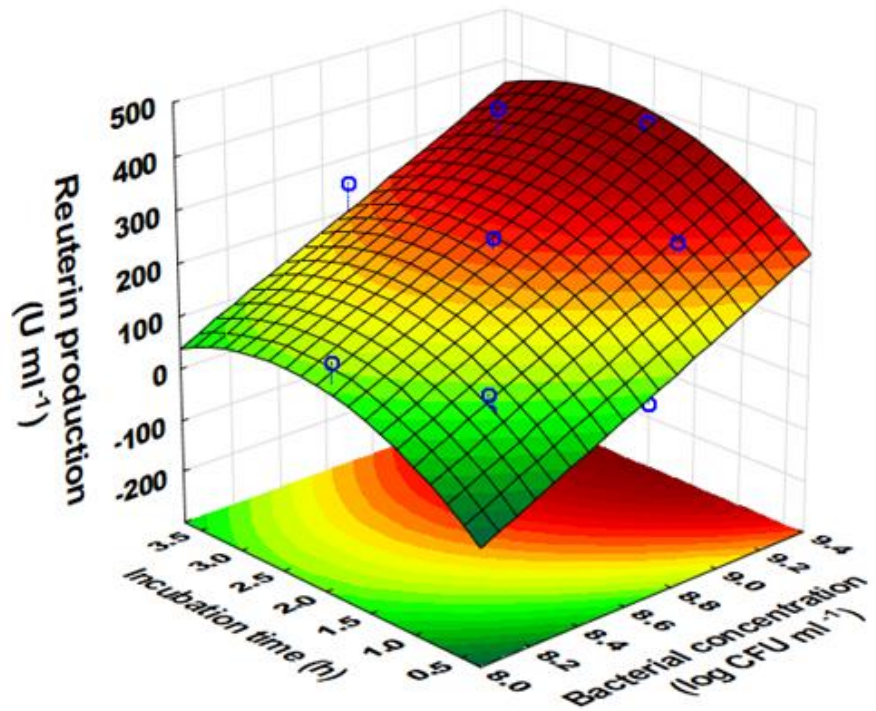

Figure 2 Effect of bacterial concentration and incubation time on reuterin production (glycerol concentration was fixed at $250 \mathrm{mM}$ )

Figure 2 presents the relation between bacterial concentration $\left(\mathrm{X}_{2}, \log \mathrm{CFU} / \mathrm{ml}\right)$ and incubation time $\left(\mathrm{X}_{3}, \mathrm{~h}\right)$ on reuterin production when glycerol concentration was kept constant at $250 \mathrm{mM}$. In general, it can be observed that the increase in bacterial concentration (from 8 to $9.4 \log \mathrm{CFU} / \mathrm{ml}$ ) and the increase in incubation time (from 0.5 to $2.5 \mathrm{~h}$ ) cause a significant increase in relative reuterin concentration; however, further increase in incubation time (more than $2.5 \mathrm{~h}$ ) of solution containing $250 \mathrm{mM}$ glycerol with irrespective of bacterial concentrations 
cause a decrease in reuterin production (Figure 2). It can be seen that high relative reuterin concentration (approximately $400 \mathrm{U} / \mathrm{ml}$ ) can be obtained using $9.4 \log \mathrm{CFU} / \mathrm{ml}$ of L. reuteri, $250 \mathrm{mM}$ glycerol and $2.5 \mathrm{~h}$ of incubation. With the same conditions but with the incubation time of $3.5 \mathrm{~h}$, only $350 \mathrm{U} / \mathrm{ml}$ against $L$. monocytogenes can be obtained.

Figure 3 presents the interactive effects between glycerol concentration $\left(\mathrm{X}_{1}, \mathrm{mM}\right)$ and bacterial concentration $\left(\mathrm{X}_{2}, \log \mathrm{CFU} / \mathrm{ml}\right)$ on reuterin production when the incubation time was kept constant at $2 \mathrm{~h}$. It can be observed that increasing both $L$. reuteri and glycerol concentrations cause an increase in reuterin production. It is of interest to observe that since the incubation time is fixed, a lower concentration of glycerol require a higher concentration of bacteria or a higher concentration of glycerol require a lower concentration of bacteria to produce similar reuterin concentration (similar antilisterial activity). For example, when glycerol concentration is around $200 \mathrm{mM}$, and bacterial concentration is around $8.8 \log \mathrm{CFU} / \mathrm{ml}$, a relative reuterin concentration of approximately $200 \mathrm{U} / \mathrm{ml}$ can be obtained. Similarly, when glycerol concentration is around $280 \mathrm{mM}$, and bacterial concentration is around $8.6 \log \mathrm{CFU} / \mathrm{ml}$, a relative reuterin concentration of approximately $200 \mathrm{U} / \mathrm{ml}$ can also be obtained. With incubation time of $2 \mathrm{~h}$, a higher relative reuterin concentration of approximately $450 \mathrm{U} / \mathrm{ml}$ can be obtained by using the bacterial concentration of approx. $9.4 \mathrm{log}$ and a glycerol concentration of 320 to $340 \mathrm{mM}$ (Figure 3). Figure 3 also showed that further increasing glycerol and bacterial concentration at fixed incubation time of $2 \mathrm{~h}$ may obtain higher relative reuterin concentration.

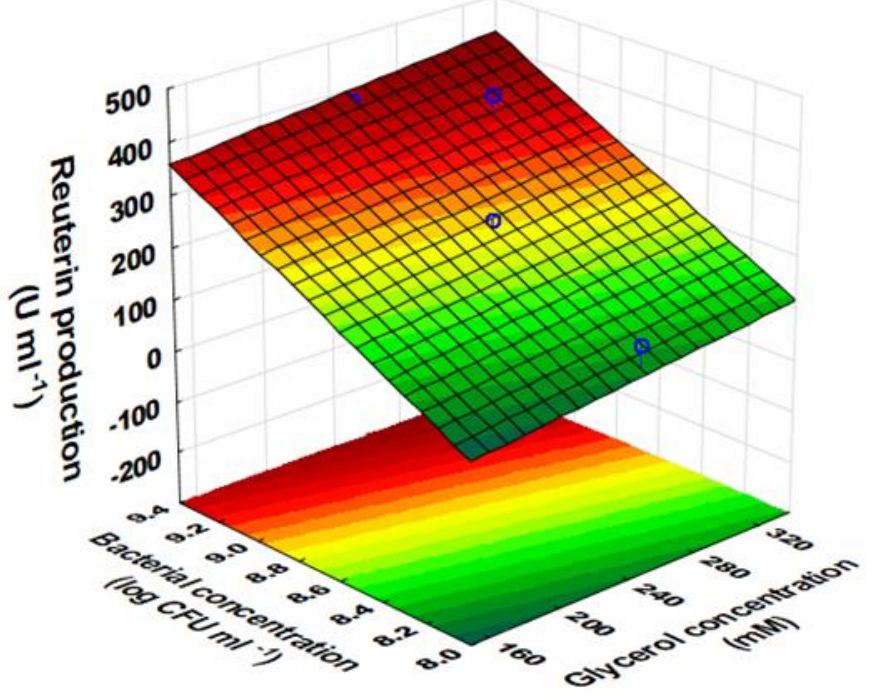

Figure 3 Effect of glycerol concentration and L. reuteri concentration on reuterin production (incubation time was fixed at $2 \mathrm{~h}$ )

\section{DISCUSSION}

Reuterin (3-hydroxypropionaldehyde, 3HPA) is a low-molecule-weight, nonproteinaceous antimicrobial substance containing aldehyde group. Reuterin is not a bacteriocin (Vollenweider and Lacroix 2004) which is different with other proteinaceous bacteriocins which are produced by many other strains of lactic acid bacteria (LAB) Turgis et al., 2013). In addition to L. reuteri, some other bacterial genera such as Klebsiela, Enterobacter, Citrobacter, Clostridium, and Bacillus can also produce reuterin (Vollenweider and Lacroix 2004).

It has been observed that E. coli strains were sensitive to reuterin than Listeria strains including L. monocytogenes (El-Ziney et al., 2000). El-Ziney and Debevere (1998) found that adding reuterin at 100 and 150 Units $\mathrm{g}^{-1}$ cheese caused a reduction of $E$. coli by 3 and $6 \log$ CFU, respectively, while a reduction of 2 and $5 \log$ was observed for L. monocytogenes at day 7 of storage. The results showed that $L$. monocytogenes was more resistant to reuterin than that $E$. coli. Thus, to apply reuterin as an antimicrobial agent against foodborne pathogens such as L. monocytogenes, a high reuterin concentration is required. Therefore, current study focused on effects of different combined conditions (Table 2) on bioconversion glycerol into reuterin by $L$. reuteri and the relative reuterin concentration was evaluated through its activity against $L$. monocytogenes.

It was found that incubation time, bacterial and glycerol concentration had positive effect on reuterin production. It showed that utilization of 320-340 mM glycerol, $9.4 \log \mathrm{CFU} / \mathrm{ml}$ of $L$. reuteri and incubation time of $2 \mathrm{~h}$, a high relative reuterin concentration of approximately $450 \mathrm{U} / \mathrm{ml}$ can be obtained (Figure 3 ). However, at a fixed concentration of bacterial and glycerol concentrations, longer incubation time caused a decrease in reuterin production. The decrease in relative reuterin concentration or its activity after long incubation time was also observed by other studies (Lüthi-Peng $\boldsymbol{e t}$ al., 2002b). The decrease in its activity could be due to reuterin was reduced to form 1,3-propanediol (Slininger et al., 1983; Talarico et al., 1990; Vollenweider and Lacroix, 2004). Further, it is also known that reuterin at high concentration can also be toxic for $L$. reuteri, the producer (Lüthi-Peng et al., 2002b; Vollenweider and Lacroix, 2004).

Concerning the mechanism of action of reuterin, it was proposed that the aldehyde group of reuterin is mainly responsible for antimicrobial activity (Schaefer et al., 2010; Vollenweider et al., 2010). Schaefer et al., (2010) demonstrated that reuterin induce oxidative stress in target organisms. The authors confirmed that the aldehyde form interacting with thiol groups of small molecules and proteins of target organisms and cause growth inhibition. When cysteine was added into growth media of E. coli or Clostridium difficile before exposing to reuterin, the antibacterial effects of reuterin against these bacteria was suppressed (Schaefer $\boldsymbol{e t}$ al., 2010). In other study, Vollenweider $\boldsymbol{e t}$ al. (2010) demonstrated that reuterin induces a depletion of reduced glutathione (GSH) in E. coli and then attack on protein- linked SH- groups, changing protein functions which finally result in cell death. Further, adding exogenous GSH caused an increase in intracellular GSH concentrations up to 9-fold and prevented the alteration of protein thiols, and resulted in rescuing the bacteria (Vollenweider et al., 2010). These properties explain for the reason why reuterin can act against a broad spectrum of bacteria, yeast, protozoa and it is a candidate for food preservation.

\section{CONCLUSIONS}

This study evaluated the bioconversion conditions including incubation time, glycerol and concentration of $L$. reuteri on reuterin production using response surface methodology and the relative reuterin concentration was expressed through its activity against $L$. monocytogenes. A polynomial predictive equation for relative reuterin concentration produced by $L$. reuteri was established Incubation time, glycerol and $L$. reuteri concentrations had positive effects on reuterin production. At a fixed concentration of bacteria, longer incubation time and low concentration of glycerol caused a decrease in reuterin production. It was found that with glycerol concentration of 320-340 mM, $9.4 \log$ CFU/ml of $L$. reuteri and $2 \mathrm{~h}$ of incubation, a high relative reuterin concentration of approximately $450 \mathrm{U} / \mathrm{ml}$ against $L$. monocytogenes can be obtained. Future study on application of reuterin alone or in combination with other antibacterial agents such as essential oils, organic acid salts to control L. monocytogenes or other foodborne pathogens in food products is necessary.

Acknowledgements: The authors sincerely thank Ministère de l'Economie, de l'innovation et des Exportation (MDEIE), Canada for financial support. Emna Lahimer and Anne-Chloé Sanchette are sincerely thanked for their technical support during this study.

\section{REFERENCES}

Adjalle, K. D., Vu, K. D., Tyagi, R. D., Brar, S. K., Valero, J. R., \& Surampalli, R. Y. (2011). Optimization of spray drying process for Bacillus thuringiensis fermented wastewater and wastewater sludge. Bioprocess Biosyst Eng, 34, 237 246. http://dx.doi.org/10.1007/s00449-010-0466-y

Arqués, J. L., Fernández, J., Gaya, P., Nuñez, M, Rodríguez, E., \& Medina M. (2004) Antimicrobial activity of reuterin in combination with nisin against foodborne pathogens. Int. J. Food Microbiol, 95, 225-229. http://dx.doi.org/10.1016/j.ijfoodmicro.2004.03.009

Arqués, J. L., Rodríguez, E., Nuñez, M., \& Medina, M. (2011). Combined effect of reuterin and lactic acid bacteria bacteriocins on the inactivation of foodborne pathogens in milk. Food Control, 22, 457-461. http://dx.doi.org/10.1016/j.foodcont.2010.09.027

Axelsson, L., Chung, T. C., Debrogosz, W. J., \& Lindgren, S. (1989). Production of a broad spectrum antimicrobial substance by Lactobacillus reuteri. Microb Ecol Health Dis, 2, 131-136. http://dx.doi.org/10.3402/mehd.v2i2.7449

Chung, T. C., Axelsson, L., Lindgren, S. E., \& Dobrogosz, W. J. (1989). In vitro studies on reuterin synthesis by Lactobacillus reuteri. Microb. Ecol. Health Dis, 2, 137-144. http://dx.doi.org/10.3402/mehd.v2i2.7450

El-Ziney, M. G., \& Debevere, J. M. (1998). The effect reuterin on Listeria monocytogenes and Escherichia coli $\mathrm{O} 157: \mathrm{H} 7$ in milk and cottage cheese. J. Food Prot, 61, 1275-1280.

El-Ziney, M. G., Bebevere, J. M., \& Jackobsen, M. (2000). Reuterin. In: Naidu, A. S. [Ed.] Natural Food Antimicrobial Systems. CRC Press, LLC, Boca Raton, Florida, USA., pp. 567-588.

Khan, A., Vu, K. D., Chauve, G., Bouchard, J., Riedl, B., \& Lacroix, M. (2014) Optimization of microfluidization for the homogeneous distribution of cellulose nanocrystals (CNCs) in biopolymeric matrix. Cellulose, 21, 3457-3468 http://dx.doi.org/10.1007/s10570-014-0361-9

Lüthi-Peng, Q., Dileme, F. B., \& Puhan, Z. (2002a). Effect of glucose on glycerol bioconversion by Lactobacillus reuteri. Appl Microbiol Biotechnol 59, 289-296. http://dx.doi.org/10.1007/s00253-002-1002-z

Lüthi-Peng, Q, Schärer, S, \& Puhan, Z. (2002b). Production and stability of 3 hydroxypropionaldehyde in Lactobacillus reuteri. Appl Microbiol Biotechnol, 60, 73-80. http://dx.doi.org/10.1007/s00253-002-1099-0 
Mechoud, M. A., Mateos, M. V., de Valdez, G. F., Villena, J., Salvador, G. A., \& Rodriguez, A.V. (2012). Lactobacillus reuteri CRL1098 soluble factors modulate tumor necrosis factor alpha production in peripheral blood mononuclear cells: Involvement of lipid rafts. Int Immunopharmacol, 14, 446-463. http://dx.doi.org/10.1016/j.intimp.2012.08.020

Montiel, R., Martín-Cabrejas, I., Langa, S., El Aouad, N., Arqués, J. L., Reyes, F., \& Medina M. (2014). Antimicrobial activity of reuterin produced by Lactobacillus reuteri on Listeria monocytogenes in cold-smoked salmon. Food Microbiol 44, 1-5. http://dx.doi.org/10.1016/j.fm.2014.05.006

Schaefer, L., Auchtung. T. A., Hermans, K. E., Whitehead, D., Borhan, B., \& Britton, R. A. (2010). The antimicrobial compound reuterin (3hydroxypropionaldehyde) induces oxidative stressvia interaction with thiol groups. Microbiol, 156, 1589-1599. http://dx.doi.org/10.1099/mic.0.035642-0

Slininger, P. J., Bothast, R. J., \& Smiley, K. L. (1983). Production of 3hydroxypropionaldehyde from glycerol. Appl Environ Microbiol, 46, 62-67.

Talarico, T. L., Axelsson, L. T., Novotny, J., Fiuzat, M., \& Dobrogosz, W. J. (1990). Utilization of glycerol as a hydrogen acceptor by Lactobacillus reuteri: Purification of 1,3-propanediol:NAD+ oxidoreductase. Appl Environ Microbiol, 56, 943-948.

Talarico, T. L., \& Dobrogosz, W. J. (1990). Purification and characterization of glycerol dehydratase from Lactobacillus reuteri. Appl Environ Microbiol, 56, 1195-1197.

Tobajas, M., Mohedano, A. F., Casas, J. A., \& Rodríguez, J. J. (2007). A kinetic study of reuterin production by Lactobacillus reuteri PRO 137 in resting cells. Biochem Eng J, 35, 218-225. http://dx.doi.org/10.1016/j.bej.2007.01.017

Turgis M., Vu, K. D., Dupont, C., \& Lacroix, M. (2012). Combined antimicrobial effects of essential oils and bacteriocins against foodborne pathogens and food spoilage bacteria. Food Res Int, 48, 696-702. http://dx.doi.org/10.1016/j.foodres.2012.06.016

Turgis, M., Vu K. D., \& Lacroix M. (2013). Partial characterization of bacteriocin-producing Enterococcus faecium isolated from human intestine. Probiotics Antimcirob Proteins, 5, 110-120. http://dx.doi.org/10.1007/s12602$\underline{013-9129-\mathrm{Z}}$

van Niel, E. W. J., Larsson, C. E., Lohmeier-Vogel, E. M., \& Rådström, P. (2012). The potential of biodetoxification activity as a probiotic property of Lactobacillus reuteri. Int J Food Microbiol, 152, 206-210. http://dx.doi.org/10.1016/j.ijfoodmicro.2011.10.007

Vancauwenberge, J. E., Slininger, P. J., \& Bothast, R. J. (1990). Bacterial conversion of glycerol to ß-hydroxypropionaldehyde. Appl Environ Microbiol, 56, 329-332.

Vollenweider, S., \& Lacroix C. (2004). 3-Hydropropionaldehyde: applications and perspectives of biotechnological production. Appl Microbiol Biotechnol, 64, 16-27. http://dx.doi.org/10.1007/s00253-003-1497-y

Vollenweider, S., Evers, S., Zurbriggen, K., \& Lacroix, C. (2010). Unraveling the hydroxypropionaldehyde (HPA) system: an active antimicrobial agent against human pathogens. J Agric Food Chem, 58, 10315-10322. http://dx.doi.org/10.1021/jf1010897 